\title{
ENTRE A DISCIPLINA, O CONTROLE E A GOVERNAMENTALIDADE NEOLIBERAL: a constituição discursiva da BNCC - Ensino Médio
}

\author{
Viviane Dinês de Oliveira Ribeiro Bartho \\ Instituto Federal de São Paulo - Campos do Jordão - IFSP/CJO, Brasil \\ Luciana Aparecida Silva de Azeredo \\ Centro Federal de Educação Tecnológica de Minas Gerais - CEFET-MG
}

\begin{abstract}
Resumo
Dentre as discussões sobre currículo, a necessidade da criação de uma base comum para a Educação Básica surgiu em 1988, a partir da Constituição, e foi reforçada pela Lei de Diretrizes e Bases da Educação de 1996. Passados mais de 30 anos da promulgação da Constituição, deparamo-nos com a versão aprovada da Base Nacional Comum Curricular (BNCC), com caráter legal e normativo. Nesse panorama, objetivamos realizar uma análise discursiva da BNCC, refletindo sobre os discursos que a constituem e sobre os vieses ideológicos que a atravessam. Delimitamos como corpus a introdução do capítulo 5 do documento, parte destinada à "Etapa do Ensino Médio", sem entrar nas orientações próprias a cada área do conhecimento. Metodologicamente, a pesquisa pode ser considerada documental, qualitativa e discursiva. Sua natureza discursiva está ancorada na Análise do Discurso Francesa (AD), tomando, sobretudo, noções desenvolvidas por Pêcheux (2014; 2015). Mobilizamos, ainda, para a interpretação objetiva dos discursos, estudos foucaultianos sobre sociedade do controle, governamentalidade, processos de subjetivação, entre outras noções teóricas. Como resultado, compreendemos a BNCC como parte da maquinaria discursiva neoliberal, operando como dispositivo de controle das práticas docentes e da formação discente, na qual o professor tem função fundamental, atuando em processos de subjetivação e no engendramento de novas subjetividades.
\end{abstract}

Palavras-chave: Análise discursiva da BNCC do Ensino Médio; AD francesa; Neoliberalismo e governamentalidade.

\begin{abstract}
Among the long-lasting discussions on curriculum, the need to create a common basis for Basic Education arose in 1988, after the promulgation of the Constitution and was reinforced by the Lei de Diretrizes e Bases da Educação (LDB) in 1996. More than 30 years after the promulgation of the Constitution, we are faced with the updated and approved version of the Base Nacional Comum Curricular (BNCC), the basis for a national curriculum, with legal and normative character. In this context, we aim to carry out a discursive analysis of the BNCC, reflecting on the discourses that constitute it and on the ideological biases present in it. We defined as a corpus the introduction of its chapter 5, related to the "High School", without dealing with the specific guidelines for each area of knowledge. Methodologically, this work is documental, qualitative and discursive, anchored in the French Discourse Analysis (AD), specifically in notions developed by Pêcheux $(2014 ; 2015)$. We also mobilized, for the objective interpretation of the discourses, Foucauldian studies on the society of control, governmentality, subjectivation processes, among others. As a result, we define and characterize the $\mathrm{BNCC}$ as part of the neoliberal discursive machinery, operating as an apparatus to control teaching practices and student training, in which the teacher has a fundamental role, acting in new processes of subjectification and, thus, in engendering new subjectivities.
\end{abstract}

Keywords: Discursive analysis of BNCC regarding High School; French AD; Neoliberalism and governmentality.

ISSN 1645-1384 (online) www.curriculosemfronteiras.org 


\section{Introdução}

O presente artigo toma a Base Nacional Comum Curricular (BNCC) como foco de investigação. Tendo sido aprovada em 2017 e configurando-se como documento nacional obrigatório - que norteará as (re)formulações curriculares de todo o país -, isto é, considerando sua presença como inevitável nas práticas pedagógicas docentes e discentes, pretendemos lançar um olhar para os discursos que a constituem e para o modo como podem afetar a formação dos sujeitos.

Especificamente, partimos de inquietações que vivenciamos em interação com outros colegas. Para ficarmos em apenas um exemplo, citaremos o caso de uma professora, colega de trabalho e de área, que externalizou sentir pouca clareza para compreender, no texto da BNCC, alguns discursos que dizíamos, à ocasião, constarem no documento. Segundo ela, os vínculos com a racionalidade neoliberal ou o conflito entre o público e o privado não estavam evidentes na materialidade linguística da base e que, portanto, as críticas que alguns autores faziam ficavam um tanto sem sustentação. Diante desse relato, observamos que a posição da professora poderia ser a de outras(os), de forma que o documento oficial viesse a ganhar um caráter de aceitação total em alguns espaços ou por alguns profissionais.

Não cabe aqui fazer uma força contrária a essa possibilidade, buscando rechaçar a BNCC a qualquer custo. De fato, esse movimento não faz parte do escopo da pesquisa. Propomos, apenas, uma leitura do texto oficial a partir de um direcionamento crítico, que busca desnaturalizar os sentidos, que procura por contradições e por vínculos discursivoideológicos que venham a explicar as relações de poder-saber e as estratégias de controle que operam no documento. Esse tipo de leitura não é uma leitura de aceitação plena, nem de resistência gratuita; é, sim, um esforço para não sucumbir aos regimes de verdade que, historicamente, nos constituem e que, embora nos subjetivem, nunca serão apreendidos de modo inequívoco e homogêneo, permitindo, sempre, brechas para novas rotas de sentidos e para novas subjetividades.

É importante refletir, também, sobre algumas provocações feitas por Favacho (2016), quando critica um caráter um tanto regulador e confortador de muitos estudos acerca de currículo. A BNCC não é propriamente um currículo, mas, pressupostamente, interferirá na (re)formulação curricular das escolas brasileiras, daí a relevância de se ater às contribuições de Favacho (2016). Segundo o autor, há uma certa constância em se afirmar (e se conformar com a ideia), pelos estudos de currículo, como esse dispositivo pedagógico, que faz parte dos regimes de verdade modernos, é uma forma de organizar os conhecimentos, impondo uma visão de mundo e reproduzindo subjetividades, dentro de uma concepção da normatização e, consequentemente, da exclusão. No entanto, embora essa seja questão corretamente debatida e compreendida, não diz tudo sobre currículo. Para o autor, baseado nos estudos de Foucault, há sempre uma parte ética que opera no processo de subjetivação humana, segundo a qual o sujeito é produto do outro (do poder, do sistema, do controle), mas também, dialeticamente, é resultante de um exercício sobre si mesmo, uma forma singular pela qual se vincula às verdades construídas. Não cabe, como bem ressalta Favacho (2016), tomar o sujeito em sua liberdade total, mas, sim, pensar como certos discursos se libertam do circuito dominante e 
ganham força para instaurar novas formas de subjetivação. É nesse movimento, segundo o autor, que as investigações sobre a experiência de si e sobre as questões éticas poderiam contribuir para outras problematizações do sujeito e dos sistemas nos quais se engendram.

Nessa forma de compreender o caminho que as pesquisas sobre currículo, recorrentemente, percorrem e os caminhos que elas poderiam percorrer, de modo muito mais frutífero, na sua visão, Favacho (2016), baseado em Foucault (2000) ${ }^{1}$, faz apontamentos para investigações a partir da noção de experiência (de si), sem cair no relativismo e nos localismos excessivos. É necessário, chama atenção, quatro questões básicas: a aposta, a homogeneidade, a sistematização e a generalidade. Para nós, neste artigo, tomaremos a fundo a questão da aposta, a qual deve ser instituída com uma constatação e, ao mesmo tempo, uma desconfiança. Assim, partimos da aposta de que a BNCC opera segundo algumas premissas básicas, como, por exemplo, a de que a "educação deve proporcionar liberdade individual do sujeito", e desconfiamos de que os discursos convirjam com os ideais de escola democrática e igualitária clamados pela população brasileira. Foi com esse tipo de aposta e de desconfiança que buscamos encaminhar nossas discussões e análises, desconfiança nem sempre vinculada às leituras mais comuns realizadas da BNCC, a qual se passa, por vezes, como marco de discurso hegemônico, sem possibilidade de contestação ou crítica. Esse tipo de leitura é, não raro, materializado na esfera escolar, dada a sua estrutura pouco aberta às possibilidades de pesquisa ou de discussões científicas e onde, frequentemente, enfatizam-se práticas de absorção e aplicação de novos métodos e inovações didático-teóricas entendidos, naturalmente, como avanços.

Não temos a pretensão de estabelecer uma nova teoria do currículo nem tampouco reproduzir críticas à BNCC, embora elas possam vir a se inscrever nas observações. Buscamos, sobretudo, lançar um olhar para esse documento que provoque certa desnaturalização de efeitos de sentido e uma possível contribuição aos professores da área da linguagem, em cujas interpretações da base pulsarão suas experiências de si mesmos. Assim, conjugando as contribuições do outro e o trabalho ético de cada sujeito, os desencadeamentos da BNCC podem vir a ser sempre outros, para além dos (im)previstos.

A partir disso, nosso objetivo é realizar uma análise discursiva da BNCC, refletindo sobre os discursos que a constituem. Delimitamos como corpus a introdução do capítulo 5 do documento, parte destinada à "Etapa do Ensino Médio", sem entrar nas orientações próprias a cada área do conhecimento. Metodologicamente, a pesquisa pode ser considerada documental, qualitativa e discursiva. Quanto à natureza discursiva, ancoramo-nos na Análise do Discurso Francesa (AD), tomando, sobretudo, noções desenvolvidas por Pêcheux (2014; 2015). Mobilizamos, ainda, para a interpretação objetiva dos discursos, estudos foucaultianos sobre sociedade do controle, governamentalidade, processos de subjetivação, entre outros.

$\mathrm{O}$ artigo está, formalmente, organizado da seguinte maneira: primeiro, apresentaremos a BNCC, seu contexto de produção e suas contradições instauradas pelo embate de interesses públicos e privados; em seguida, abordaremos a metodologia de análise, elucidando conceitos importantes com os quais operaremos analiticamente; depois, discutiremos alguns conceitos teóricos que auxiliarão na interpretação dos discursos rastreados na base, como o conceito de governamentalidade neoliberal, a teoria do capital humano, bem como a 
abordagem do currículo como elemento de subjetivação; por fim, segue a análise da parte delimitada do documento, subdividida em algumas seções em que evidenciaremos os discursos predominantes.

\section{A BNCC: contexto de produção e contradições anunciadas}

A BNCC, com início de tramitação em 2014, contou com três versões, sendo a última a mais criticada e alvo de grandes controversas. Em 2017, foi aprovada a última versão, disponibilizada atualmente no site do Ministério da Educação (MEC). Segundo Peroni, Caetano e Arelaro (2019), o texto da base foi engendrado em um contexto em que se observam, claramente, as disputas por espaço na educação brasileira, sobretudo na pública, e foi marcado por um processo não transparente e antidemocrático.

Peroni, Caetano e Arelaro (2019), discutindo ainda esse contexto, desvendam os aspectos histórico-sociais e ideológicos que incrustam a base nacional. Segundo esses autores, há uma fusão, na educação brasileira em geral e na BNCC em particular, entre o âmbito público e o privado, em que os interesses daquele ficam subjugados aos interesses deste. Os pesquisadores indicam a mercantilização e a privatização da educação e explicam o problema:

Observamos, em parte, o poder público assumindo a lógica do privado na administração pública, através da gestão gerencial e, também, quando abre mão de decidir o conteúdo da educação, repassando a direção para instituições privadas. Nesse caso, a propriedade permanece pública, mas a direção do conteúdo das políticas educativas é repassada para o setor privado. As instituições públicas, se democráticas, são permeáveis à correlação de forças, com processos decisórios em que não se tem previamente o controle do produto. São instituições de propriedade pública, mas se o processo decisório está ausente, já que tudo é previamente definido e monitorado por uma instituição privada e os professores apenas executam tarefas, entendemos que este também é um processo de privatização da educação. (PERONI; CAETANO; ARELARO, 2019. p. 38).

É clara a racionalidade neoliberal que avança sobre as questões de educação do país e do mundo, de modo geral. Também se observa a presença de um discurso neoconservador. Os pesquisadores pontuam que tanto o neoliberalismo quanto o neoconservadorismo mantêm semelhanças e diferenças. O corporativismo, o zelo pela iniciativa privada, o desejo por uma retomada de poder (supostamente esvaziado) da classe dominante, o descrédito na democracia seriam alguns dos pontos em comum. Já a interpretação de mudanças sociais como "caos da sociedade" e a moralidade rígida são características típicas do neoconservadorismo, que o afastam do neoliberalismo. Neste artigo, voltamos nossa atenção para a construção de discursos neoliberais que se materializaram na BNCC, em um projeto de educação que visa à formação de sujeitos flexíveis e aptos a exercer mão de obra adequada ao sistema empresarial e capitalista. 
Como já mencionado, a BNCC começou a ser elaborada em 2014. Sua primeira versão foi aprovada em 2016. A terceira, em 2017, já contava com muitas críticas e falta de transparência. Com base em informações apresentadas por Peroni, Caetano e Arelaro (2019), participaram da elaboração do documento os seguintes agentes privados: Fundação Santillana e Abrelivros, Itaú-Unibanco, Instituto Ayrton Senna, Insper, Fundação Roberto Marinho, Instituto Natura e o Movimento Todos pela Educação etc. Esses agentes são produtores de materiais didáticos e alguns oferecem cursos de formação continuada a professores. Entre os agentes públicos, estiveram presentes secretarias atreladas a governos do PSDB, como de São Paulo, Salvador, Goiás, Paraná; a Undime, como representante dos secretários municipais de educação do país; e o Consed, que representava os secretários estaduais de educação. Ademais, houve atuação do INEP, do MEC e do Conselho Nacional de Educação. Concordamos com os autores, que afirmam que o grupo formado é um grupo hegemônico, "que representa uma classe, em relação a um projeto educacional para o país" (PERONI; CAETANO; ARELARO, 2019, p. 45). As instituições privadas que compuseram esse bloco pretendem direcionar mudanças no sistema educacional brasileiro, no que diz respeito ao currículo e às avaliações, além, claro, à formação de professores. A BNCC é considerada a mola propulsora dessa engrenagem, em que todos dependem de "conhecimentos" e "práticas" novas que, por sua vez, poderão ser comercializados por essas instituições. Nisso se incluem as reformulações de livros didáticos e de programas de cursos de licenciatura. O caráter obrigatório da base, além de ignorar as peculiaridades das localidades e a pluralidade do país, tem a função de alinhar todo o sistema: formação de professores, livros e materiais didáticos, avaliações, conduzindo uma reforma do ensino. $\mathrm{O}$ que se enfatiza com a questão de reforma não é se ela se faz necessária ou não. Todos sabemos que a educação brasileira, sobretudo a pública, tem precariedades e precisa ser repensada. $\mathrm{O}$ que se questiona, entretanto, é o projeto que encaminha essa reforma; um projeto que, como bem esclarecem Peroni, Caetano e Arelaro (2019), tem finalidades neoliberais, as quais atendem a uma parte da população e mantêm a grande maioria em situação desigual e subalterna.

Nesse mesmo raciocínio, podemos refletir sobre a forma como os conteúdos ou as abordagens de ensino-aprendizagem foram eleitos para compor a base. As competências socioemocionais, por exemplo, foram "sugestões" do Instituto Ayrton Senna, que havia criado em 2015 um laboratório que estuda essas competências e propõe um sistema de avaliação delas. Segundo Peroni, Caetano e Arelaro (2019, p. 5), o laboratório "atua como think thank promovendo workshops, seminários em parceria com instituições do Movimento pela Base, Consed, Undime, Unesco e OCDE, visando a influenciar a BNCC". Assim, o que deve ser problematizado não é a relevância ou não das competências socioemocionais, mas, sim, qual o significado de uma entidade privada definir um conteúdo para um documento oficial, nacional, de execução obrigatória.

Dessa forma, trabalhando com a AD francesa, segundo a qual os discursos pertencem a formações discursivas e ideológicas heterogêneas e podem ser rastreados e interpretados por meio da materialidade linguístico-enunciativa, compreendemos que muito do que se propõe como direcionamentos conceituais, metodológicos, práticos, funcionais, didáticos etc. pode 
ter efeitos de sentidos não convergentes com uma educação que vá ao encontro dos anseios populares e dos pressupostos de uma educação libertadora, ancorada em Paulo Freire (2005), patrono da educação brasileira. Em outros termos, discursos materializados na BNCC podem parecer, à primeira vista, vinculados a uma formação discursiva que tem como fundamento a pedagogia freiriana e que busca a formação de sujeitos críticos, autônomos e conscientes de sua realidade e das contradições sociais, sendo, assim, capazes de questionar essa realidade e de se engajar em transformações dela. No entanto, analisando os discursos concretizados na base, pode-se perceber uma outra ancoragem, que produz efeitos de sentido neoliberais, os quais, em linhas gerais, trabalham em processos de subjetivação de sujeitos flexíveis, competentes e habilidosos para o mercado de trabalho, além de aptos para se adaptarem às realidades (a)diversas, não necessariamente para modificá-las. Este segundo tipo de formação se contradiz, por conseguinte, com os pressupostos de sociedade politizada e transformadora.

Assim, partimos da hipótese dessa contradição inscrita na BNCC, revelada por leituras do documento e por compreensões do contexto histórico-social que o circunda e o produziu. Partimos, também, da busca por contribuições aos professores e a todos aqueles ligados à educação, objetivando oferecer uma versão de leitura crítica da base.

\section{Metodologia de análise}

Orlandi (2005) explica, no âmbito da AD construída por Pêcheux (2014), que há uma relação intrínseca entre língua, discurso e ideologia. O discurso é a materialidade da ideologia; a língua, a materialidade do discurso. Dessa forma, o discurso é tomado como objeto pelo qual se pode observar o sujeito, que é um sujeito de linguagem e de ideologia. Em outros termos, acessando os discursos, é possível observar como o sujeito produz sentidos, a partir de sua formação ideológica e de seu trabalho com a língua. O discurso é, portanto, nosso ponto de análise, e a busca por interpretá-lo se dará por meio de sua materialidade, a língua, realizada em enunciados e textos. No nosso caso específico, o texto da BNCC será tomado como espaço discursivo a ser investigado.

Os textos e os enunciados não carregam em si os sentidos, mas oferecem vestígios e indícios dos efeitos de sentido (dos discursos) que neles foram inscritos pelos sujeitos. Os sentidos se manifestam, não apenas segundo as posições dos sujeitos, mas também em relação às formações ideológicas nas quais essas posições se inscrevem, que apontam para a formação discursiva (FD), para "aquilo que numa formação ideológica dada - ou seja, a partir de uma posição dada em uma conjuntura sócio-histórica dada - determina o que deve ser dito" (ORLANDI, 2005, p. 43). Uma formação discursiva (FD) revela as formações ideológicas que a integram e, em seu interior, há a presença de vários discursos, elementos vindos de outras formações discursivas. Em outros termos, "em toda e qualquer formação discursiva, as contradições representam uma coerência visto que desvelam elementos exteriores à materialidade linguística, mas inerentes à constitutividade dos discursos e dos sujeitos" (FERNANDES, 2007, p. 75). Partindo dessas considerações, podemos afirmar que 
o(s) sentido(s) de um mesmo enunciado e/ou de uma mesma palavra nunca será/ão o(s) mesmo(s), devido à inscrição dos sujeitos em diferentes FD. Dito de outro modo,

[...] as palavras não são só nossas. Elas significam pela história e pela língua. O que é dito em outro lugar também significa nas "nossas" palavras. O sujeito diz, pensa que sabe o que diz, mas não tem acesso ou controle sobre o modo pelo qual os sentidos se constituem nele (ORLANDI, 2005. p. 32).

Por isso, quando se fala, por exemplo, em sujeito autônomo na BNCC, precisa-se analisar à qual formação discursivo-ideológica os efeitos de sentido estão relacionados: se são sentidos de uma proposta de educação politizada e transformadora ou se são efeitos que encaminham para uma concepção de educação vista como mercadoria e/ou como investimento, entendida como estratégia de aumento de capital humano, logo, como parte de uma educação neoliberal. São esses percursos de sentido que pretendemos rastrear na versão da base aprovada.

\section{Fundamentação teórica}

As primeiras leituras da base nos levaram à delimitação e à mobilização de conceitos foucaultianos para compreendê-la melhor. Como se verá nas análises, muitos dos discursos concretizados no texto da BNCC encontram eco nas discussões de Foucault e seus estudos sobre as relações saber/poder, processos de subjetivação, regimes de verdade, sociedade disciplinar e de controle e, sobretudo, sobre a racionalidade neoliberal surgida desde a segunda metade do século XX. Desse modo, baseando-nos em Foucault $(1987,2008)$ e em autores que tomam seus conceitos como norte para refletir sobre educação, discutiremos algumas noções e seus desdobramentos para o campo educacional. Em linhas gerais, concentrar-nos-emos nas questões da governamentalidade neoliberal e na teoria do capital humano, ambas imbricadas na construção da lógica do neoliberalismo. Por fim, refletiremos, com base em Veiga-Neto (2008), sobre as transformações e o papel do currículo escolar, encaminhando para enfocarmos as questões envolvidas na BNCC.

\subsection{Governamentalidade Neoliberal e a Teoria do Capital Humano²}

Os primeiros estudos de Foucault tomavam o poder como força produtora de subjetividades (a obra "História da Loucura" é um exemplo). Para o pesquisador francês, o poder se incrustava nos dispositivos disciplinadores e normalizadores, que eram responsáveis pela acomodação dos sujeitos em identidades dóceis. Esse efeito hierarquicamente verticalizado se pautava pela força violenta sobre o corpo. Embora concentrado na figura do Estado, espalhava-se pelo tecido social por meio das instituições, que funcionavam para a 
transmissão e manutenção da ordem. A disciplina e a docilidade dos sujeitos eram o mais importante.

Já em História da Sexualidade (1988), em Vigiar e Punir (1987), entre outras obras, Foucault passa a discutir os modos de controle, os quais ganhariam ênfase em relação aos dispositivos disciplinadores. Os modos de objetivação foram aperfeiçoados em técnicas e métodos de vigilância para a disciplina e, sobretudo, para o controle. Não que controle tenha substituído a ideia de disciplina, mas as ênfases e os objetivos foram transformados. Assim, se antes o poder se estabelecia pelos dispositivos de opressão; depois pelos dispositivos disciplinares; na modernidade, ele emerge como estabelecedor do controle e da ordem; e, na contemporaneidade, surge como arte de governar ou como uma governamentalidade.

Por governamentalidade, entende-se ser o "[...] encontro entre as técnicas de dominação exercidas sobre os outros e as técnicas de si" (FOUCAULT, 1994, p. 786 Apud FONTOURA, 2008, p. 19). É uma arte de governar inscrita no movimento da racionalidade neoliberal, segundo a qual o poder do Estado se espalha por técnicas de dominação e controle, ao mesmo tempo em que os sujeitos respondem aos efeitos desse poder nas diferentes formas ou estéticas de existência. Em outros termos, governamentalidade é junção de "governar" e de "mentalidade" para enfatizar "a interdependência entre o exercício do governamento (práticas) e as mentalidades que sustentam tais práticas" (FIMYAR, 2009, p. 38). Dito de outro modo, "os estudos de governamentalidade examinam também as relações entre as formas e as racionalidades de poder e os processos de subjetivação - formação de sujeitos/cidadãos governáveis - e a subjetificação - formação da existência individual" (FIMYAR, 2009, p. 37).

Respaldando-se nos estudos foucaultianos, principalmente nas aulas proferidas por ele no Collège de France, entre 1978 e 1979, Costa (2009) reflete especificamente sobre o contexto escolar, que não foi alvo das ideias do filósofo francês, mas também não foi ignorado por ele. Segundo Costa (2009), valores econômicos migraram da economia para outros setores da sociedade, disseminando-se por meio de políticas e processos de subjetivação e atuando no engendramento de novas subjetividades, vistas como microempresas. Essa compreensão se inscreve no âmbito das discussões sobre a biopolítica e a governamentalidade, sendo aquela uma característica desta.

Nesses estudos, detidamente em reflexões que abordam o neoliberalismo como racionalidade de Estado e como lógica de subjetivação dos sujeitos, Foucault (2008) apresenta o homo oeconomicus: "No neoliberalismo - e ele não esconde, ele proclama isso , também vai-se encontrar uma teoria do homo oeconomicus, mas o homo oeconomicus, aqui, não é em absoluto um parceiro de troca. O homo oeconomicus é um empresário, e um empresário de si mesmo (FOUCAULT, 2008, p. 310 e 311. Destaque do autor).

Partindo dessa análise da perspectiva neoliberal, cujo berço intelectual foi a Escola de Chicago, na primeira metade do século XX, Foucault elucida que houve uma mudança de valores e práticas em relação ao modelo liberal de mercado. Assim, nas palavras de Costa (2009):

[...] já não faria muito sentido pensar o indivíduo e o capital como exteriores um ao outro - por exemplo, quando se diz que alguém, um banqueiro ou um executivo 
de uma grande transnacional, é representante do capital; ou, inversamente, quando se diz que alguém, um operário, um professor ou um programador na área da informática, é objeto de exploração do capital. Pois, sob a sua ótica, as competências, as habilidades e as aptidões de um indivíduo qualquer constituem, elas mesmas, pelo menos virtualmente e relativamente independente de classe social a que ele pertence, seu capital; mais do que isso, é esse mesmo indivíduo que se vê induzido, sob essa lógica, a tomar a si mesmo como um capital, a entreter consigo (e com os outros) uma relação na qual ele se reconhece (e aos outros) como uma microempresa; e, portanto, nessa condição, a ver-se como entidade que funciona sob o imperativo permanente de fazer investimentos em si mesmo - ou que retornem, a médio e/ou longo prazo, em seu benefício - e a produzir fluxos de renda, avaliando racionalmente as relações de custo/benefício que suas decisões implicam. (COSTA, 2009, p. 177).

Nesse sentido, Costa (2009, p. 177) complementa a ideia e encaminha a concepção de Capital Humano, essencial para o funcionamento de um sistema neoliberal:

O indivíduo moderno, a que se qualificava como sujeito de direitos, transmuta-se, assim, num indivíduo-microempresa: Você S/A. E é justamente por isso que a economia, desde então, já não se resume à preocupação com a lógica histórica de processos ligados à produção, mas passa a se concentrar nos modos mediantes os quais os indivíduos buscam produzir e acumular capital humano.

Toda a sociedade se transforma numa sociedade de empresa (empresarial ou de serviços), de maneira que cada indivíduo invista cada vez mais em si mesmo e estabeleça entre si e os outros um forte vínculo de competitividade e de concorrência. Aliás, a ideia constitutiva dos sujeitos de que estão em incessante concorrência com os outros é que faz operar a lógica do neoliberalismo. Nas palavras de Simon e Masschelein (2011, p. 124), o "[...] governo de si empresarial implica o olhar para si mesmo como habitante de um ambiente particular, que tem necessidades e que produz bens (ou mesmo investe em capital humano) com o propósito de conhecer e satisfazer essas necessidades". Sem o imperativo da busca por aumentar o capital humano, por investir em si mesmo, os discursos neoliberais não encontrariam adesão. Com eles, emerge o individualismo ao extremo, fragilizando a noção de coletividade e a credibilidade nela. Assim, a racionalidade política neoliberal atua para transformar os indivíduos em microempresas que comercializam as próprias relações humanas de modo concorrencial e, para ganhar nas disputas, esses indivíduos devem ampliar e enriquecer seu capital humano.

Essa ideia de capital humano, que emergiu em meio à lógica de mercado, foi se espalhando para outros âmbitos sociais, como a escola, vista como importante espaço estratégico de aumento de capital humano. Para Costa (2009, p. 177),

[...] a estreita interface dessa teoria do Capital Humano com a educação está, portanto, na importância que a primeira atribui à segunda, no sentido desta última funcionar como investimento cuja acumulação permitiria não só o aumento da 
produtividade do indivíduo-trabalhador, mas também a maximização crescente de seus rendimentos ao longo da vida.

A formação inicial e continuada e a capacitação profissional em geral dos indivíduos são entendidas, nessa ótica, como elemento estratégico a ser investido pelas práticas da governamentalidade. Os currículos, as metodologias, as práticas pedagógicas voltam-se para a formação de um sujeito com um conjunto de habilidades e competências que detém um valor de mercado e é ele próprio compreendido como uma forma de capital, o capital humano.

$\mathrm{Na}$ escola, vemos a cultura do empreendedorismo ligada à teoria do capital humano. A cultura empreendedora como competência a ser desenvolvida passa-se como um fator de progresso, como um modo de desenvolvimento sustentável para o bem-estar social (COSTA, 2009). No entanto, não são explicitadas e discutidas as pretensões neoliberais ou os efeitos dessa racionalidade. Na justificativa de alguns autores para a defesa do empreendedorismo na escola, há sempre o pressuposto de que a sociedade não é participativa, não é ativa, não contribui suficientemente bem para o desenvolvimento de seu país. Há uma tendência discursiva que culpabiliza a própria população trabalhadora por seu insucesso, ou seu desemprego, por suas dificuldades socioeconômicas, ou mesmo, pelos obstáculos que o país enfrenta para o desenvolvimento pleno. Isso fica claro em argumentações com esta:

[...] investir no empreendedorismo parece ser a melhor solução. Mais que um programa social, isso significa uma visão de mundo e de vida, um compromisso político de todo cidadão com a nação e o planeta. As instituições educacionais podem colaborar na solução dessas dificuldades socioeconômicas, preparando pessoas para empreender, gerar empregos, criar riquezas para o país. Precisamos de um povo participativo, sensível, produtivo [...]. (ACÚRCIO; ANDRADE, 2005, p. 12 Apud COSTA, 2009, p. 181).

Silva e Barreiro (2019) esclarecem, ainda, que, no modelo social neoliberal, a escola pública tem sua eficácia, em termos de resultados, sempre questionada. É uma postura de contestação que colocaria a instituição escolar sempre em descrédito, visando, no fundo, desqualificar a capacidade de gestões públicas. Nessa esteira, não colocar a escola na lógica de mercado significaria abandoná-la à precarização. Também os docentes e os discentes, não encontrando suposto motivo para aprimoramento profissional e pessoal, ficariam na condição de desqualificados, reforçando a ideia de ensino precarizado. Todas essas discursividades corroboram com o intuito neoliberal, que pretende se estabelecer na escola para geri-la e para, por meio dela, concretizar uma potente estratégia de formação de indivíduos prontos e instrumentalizados para o mercado de trabalho no qual são eles mesmos os "donos de capital", seu capital humano. Percebem-se as ideias de liberdade individual e de responsabilização reforçadas e desvinculadas das questões de classe.

Há, na lógica neoliberal, o imperativo pela inovação e pelo "aprender a aprender", ou seja, pela iniciativa individual de se responsabilizar pelo investimento em si e pela colheita dos resultados desse "mérito". A máscara da coletividade, ou melhor, do "trabalho 
colaborativo" e "de equipe", conforme vocabulário empresarial típico, apenas opera para ofuscar o processo de individualização extrema dos sujeitos, que são, ao mesmo tempo, incitados à concorrência. Nesse sentido, observam-se cada vez mais a passividade política (ou a despolitização) e a fragilização da ideia de coletividade, de modo que sobressai o impulso do "cada um por si" (COSTA, 2009).

A teoria do Capital Humano e a cultura do empreendedorismo estão ligadas e intensamente presentes na escola por meio de currículos voltados ao desenvolvimento de habilidades e competências (tanto na formação do professor quanto na do aluno), bem como por meio de modos de avaliação ao estilo de gestão empresarial, e por meio de todas as práticas que se alinham a valores e concepções neoliberais de vida e de relações sociais. Salientamos, nesse ponto, que problematizar os conceitos de habilidades, competências e avaliação será foco de outros artigos.

Alguns traços se destacam e se repetem na constatação do sujeito produzido pelo neoliberalismo: proatividade, inovação, invenção, criatividade, flexibilidade, adaptabilidade; e são nesses traços em que os currículos escolares vão se pautar ao elaborar o conjunto de conteúdos, os planejamentos e todo norteamento de práticas de controle e de subjetivação, uma vez que a instituição escolar passa a ser instância privilegiada de disseminação dos valores econômicos, que constituem o novo regime de verdade:

Tendo na economia e no mercado sua chave de decifração, seu princípio de inteligibilidade, trata-se de uma governamentalidade que busca programar estrategicamente as atividades e os comportamentos dos indivíduos; trata-se, em última instância, de um tipo de governamentalidade que busca programá-los e controlá-los em suas formas de agir, de sentir, de pensar e de situar-se diante de si mesmos, da vida que levam e do mundo em que vivem, através de determinados processos e políticas de subjetivação: novas tecnologias gerenciais no campo da administração (management), práticas e saberes psicológicos voltados à dinâmica e à gestão de grupos e das organizações, propaganda, publicidade, marketing, branding, literatura de autoajuda etc.” (COSTA, 2009, p. 178).

Os apelos na escola para o desenvolvimento de competência empreendedora, espírito de inovação e participação ativa revelam, na verdade, uma formação ideológica que entende o sujeito com plena liberdade de escolha. As más escolhas ou a falta de conhecimento para fazê-las levariam esse sujeito ao fracasso. A visão de que a sociedade é passiva (até preguiçosa) e sem iniciativa para modificar sua condição socioeconômica se impregna nessa ideologia. Consequentemente, ficam subjugadas as análises de classe social, de estrutura histórica, de contextos culturais. Ficam suprimidas, ademais, as discussões sobre as contradições do sistema capitalista, os efeitos de dominação ideológica e financeira, bem como não se põe em xeque o status quo e não são pensados espaços de construção coletiva para reversão da realidade desigual que acomete a maior parte da sociedade de países como o Brasil. A ideia de coletividade, aliás, vai paulatinamente sendo minada e fragilizada, conforme se comentou anteriormente. 


\subsection{O currículo escolar como componente da subjetivação neoliberal}

$\mathrm{Na}$ análise de Batista (2019), Foucault anuncia que, já no modelo do liberalismo, havia sido revelada uma mudança de ênfase segundo a qual se encaminha a governamentalidade. As relações de poder-saber que disciplinavam o corpo e as práticas perderam ênfase em favor da potencialização de dispositivos criados para gerir a população e incentivar interesses individuais. A noção de controle passou a ser mais produtiva que a de disciplinamento, mesmo que esta segunda continuasse a operar por práticas discursivas e não discursivas. $\mathrm{O}$ que se observou, entretanto, foi uma mudança de ênfase - da disciplina para o controle.

Além disso, o neoliberalismo passou a demandar uma outra subjetividade, diferente da do liberalismo, que o atendesse. Baseado em Deleuze (1992) ${ }^{3}$, Batista (2019) explica que

[...] o modelo de fábrica concentrava os seus trabalhadores rigidamente, distribuindo-os no espaço e ordenando-os no tempo. Já a empresa, ao contrário, não compra matéria-prima nem vende produtos acabados: ela exerce um capitalismo de sobreprodução, que vende serviços e compra ações, em vez de bens materiais. Portanto, a sua configuração é dispersa, e não enraizada. Ela exige a presença de trabalhadores dinâmicos, que vão de um lugar a outro, usando-os e abandonando-os. E especializam-se em deixar para trás e darem atenção ao que lhes parece mais rentável em determinado momento. [...] (BATISTA, 2019, p. 153).

Essa modificação com relação à ênfase dada à produção de corpos dóceis e disciplinados para à de corpos controláveis pode ser encontrada, na escola, por exemplo, em análises da produção de seus currículos. Discutindo essa questão, Veiga-Neto (2008) pontua que os quatro elementos constitutivos do currículo passam por mudanças e transformações: planejamento de objetivos, seleção de conteúdos, colocação dos conteúdos em ação (organização da prática) e avaliação. $\mathrm{O}$ autor considera que a mudança de ênfase da lógica social é incorporada nas lógicas curriculares, reduzindo a ênfase na disciplina e aumentandoa no controle. Isso porque, como ele explica, há uma mudança da organização moderna da sociedade para uma organização pós-moderna, na qual se destacam as características de liquidez e flexibilidade dos sujeitos, das práticas, das instituições, das relações sociais.

As transformações curriculares são uma das manifestações dessa mudança do moderno para o pós-moderno, um pós-moderno profundamente engendrado na racionalidade neoliberal. A passagem da Modernidade para a Pós-modernidade tem sido caracterizada por crise ou rupturas de paradigmas. Nesse sentido, o autor entende que há uma passagem que diferencia, de um lado - mas não de forma oposta, apenas diferente nas ênfases, já que um processo não se finaliza para que outro seja iniciado -, a disciplina moderna, que busca produzir corpos dóceis, e, de outro lado, o controle pós-moderno, que opera na produção de corpos flexíveis e adaptáveis.

Antes do aprofundamento na questão, Veiga-Neto (2008) faz um esclarecimento importante. Ressalta que não cabe pensar a escola apenas como produzida por uma sociedade, 
mas também como produtora dessa sociedade. Assim, nessa relação dialética, a escola, ao longo do período moderno, "estabeleceu-se como uma grande maquinaria social e cultural, ou seja, como um grande conjunto de 'máquinas' que, operando articuladamente entre si, desempenham um papel crucial para a formação política, cultural e econômica da sociedade ocidental" (VEIGA-NETO, 2008, p. 142). Articulados a essa maquinaria, foram criados espaços, saberes, especialistas, entre outros elementos com a função de apontar como deve ser a educação. A escola tornou-se, pois, uma instituição privilegiada na Modernidade para o direcionamento de saberes pedagógicos e de conceitos, conforme explica o autor, tomando como referência estudos de Varela e Alvarez-Uría (1991) e Marshall (1994) ${ }^{4}$.

É quase óbvio, por conseguinte, que a chamada crise da Modernidade atinja a escola e toda a maquinaria discursiva pela qual ela foi estruturada. Crise, analisada por Veiga-Neto (2008), não como acontecimento negativo - sentido influenciado pela prática médica -, mas como transformação ou superação de um modelo/paradigma ou mesmo como a sensação advinda da "diferença entre o esperado, sonhado, desejado e o obtido, atualizado, conseguido" (VEIGA-NETO, 2008, p. 143). Como na contemporaneidade, essa diferença se amplia, na medida em que tomamos como referência valores e práticas modernas, a sensação de crise também se intensifica. Ademais, quanto mais as forças para dominar e controlar a sociedade tentam administrá-la e prever suas condutas, mais o aspecto inapreensível do acontecimento torna-se visível, o que amplifica a sensação de que as coisas estão fora de seu "devido" lugar.

Para além do contexto de crise, o que se enfoca com essas reflexões são as formas de subjetivação que são desencadeadas pelos aspectos típicos da Pós-modernidade. A solidez da identidade moderna, os sistemas disciplinares como gerência social e o assujeitamento subjetivo às/pelas formas de poder abriram espaço para o funcionamento de outro circuito: o da volatilidade, da flexibilidade, do borramento ou apagamento de fronteiras que, conjugados, desvendam o caráter instável e não permanente do funcionamento do mundo pós-moderno e, consequentemente, das novas subjetividades.

A escola, com seus dispositivos disciplinares, atua na produção do sujeito disciplinar. Dito de outro modo, a maquinaria escolar, composta por currículo, organização espacial, panóptico, fichas, exames etc., operou na produção da sociedade disciplinar como vimos atualmente. Nesse contexto, Veiga-Neto (2008) lança um olhar para o currículo, inventado, segundo ele, no final do século XVI. Sobre essa invenção, o autor esclarece: “[...] na medida em que o currículo foi artefato que articulou disciplinarmente as práticas e os saberes escolares, pode-se dizer que, desde sua criação, ele esteve intimamente conectado à fabricação do sujeito e da própria Modernidade [...]” (VEIGA-NETO, 2008, p. 145). Detalhadamente, o autor define e caracteriza currículo como um conjunto organizado de conhecimentos escolares que

[...] assumiu para si a lógica disciplinar, levando-a a um desenvolvimento notável, tanto em termos do eixo corporal - disciplina-corpo - quanto em termos do eixo saberes - disciplina-saber. Em qualquer caso, as disciplinas são partições e repartições - de saberes e de comportamentos - que estabelecem campos 
especiais, específicos, de permissões e interdições, de modo que elas delimitam o que pode ser dito/ pensado e feito ("contra" o que não pode ser dito/ pensado e feito) [...] (VEIGA-NETO, 2008, p. 145).

Veiga-Neto (2008) relaciona currículo com a noção de dispositivo, de Foucault. Isso porque, um dispositivo "designa todo um conjunto de práticas discursivas e não discursivas cujos elementos são heterogêneos mas se mantêm conectados numa rede de relações" (VEIGA-NETO, 2008, p. 145); além disso, nessa rede se materializam em práticas instituições correlatas que apresentam funções estratégicas para "manter o poder de uns sobre os outros, a ação de uns sobre as ações dos outros” (VEIGA-NETO, 2008, p. 145). Assim, o currículo se corporifica em conteúdos e formas e opera, na escola moderna, para a instituição do pensamento disciplinar, tornando-se um modo de objetivação e de subjetivação (POPKEWITZ, $1994^{5}$ Apud VEIGA-NETO, 2008).

No entanto, se a crise se instaurou sobre todo o tecido moderno, lançando luz a uma organização pós-moderna, a escola e, por extensão, o currículo não ficaram à parte desse contexto. Especificamente sobre o currículo, observa-se a crise sobre a noção de disciplina: seria a crise da disciplinaridade, tanto em relação à disciplina vinculada à organização do saber como em relação à disciplina do corpo. Em resposta a essa crise, Veiga-Neto (2008) cita o exemplo da transdisciplinaridade, como tentativa de ultrapassar a ideia de disciplinaridade, e o refinamento de técnicas de controle para conter a (in)disciplina escolar. Esses exemplos, entretanto, apenas desnudam que o currículo foi "[...] pensado e organizado como um artefato hierarquizado, sólido, confiável, estável, perene -, 'arrastado' pela crise da disciplinaridade entra[m] também em crise. A disciplina transporta para o currículo a crise que ela mesma atravessa" (VEIGA-NETO, 2008, p. 146).

$\mathrm{O}$ autor explica, então, que, devido ao imperativo de mudança de ênfase da disciplina para o controle, os currículos tendem a seguir esse movimento, pensando novos procedimentos de controle. Perdem interesse o planejamento de objetivos e a seleção de conteúdos. Canaliza-se atenção aos modos como os conteúdos serão colocados em ação na prática pedagógica e aos modos de avaliação. Dessa maneira, os novos sistemas de controle serão pensados e criados. No campo educacional, surgem as demandas por relatórios, formulários, cadastros, avaliações escritas, registros de aulas, planejamentos, planos de ensino, tudo para compor um grande banco de dados que poderá ser consultado e fiscalizado a qualquer momento. Também as mudanças constantes nos formatos desses materiais, acompanhando novas metodologias, inovações teóricas e práticas, fazem parte dos sistemas de controle, em constante movência, com a roupagem da atualização, mas que buscam, na verdade, capturar o sujeito e controlá-lo, fato que denuncia, na verdade, a condição cada vez mais incontrolável e líquida da Pós-modernidade, frente ao corpo dócil e disciplinado da Modernidade.

É nesse sentido que compreendemos a BNCC, como dispositivo de controle das práticas docentes e das práticas avaliativas, em suma, do próprio professor e da formação discente na qual o professor tem papel imprescindível. Esse documento normativo, que vai regulamentar toda construção curricular no país, atua, junto a outros elementos da maquinaria escolar, na 
instauração de novos processos de subjetivação e, assim, no engendramento de novos sujeitos, que serão, como vimos, formados na e para a lógica neoliberal, a fim de atender ao sistema econômico e de trabalho.

\section{Análise discursiva da BNCC}

Após uma etapa de descrição da materialidade discursiva da BNCC e após os procedimentos de análise objetiva dessa materialidade, pautados por conceitos da AD francesa, conforme elucidados na seção de metodologia, e por conceitos foucaultianos, mobilizados como dispositivos interpretativos, pudemos observar alguns campos discursivos, que foram organizados por nós nas subseções a seguir. Entendemos que esses campos são atravessados por um ou mais discursos que ganham ênfase, mas não anulam outros; a divisão é, pois, apenas uma opção norteadora. O que fica evidente é que a rede discursiva formada no texto da base converge para um projeto educacional de caráter neoliberal e, ao mesmo tempo, procura diálogos com outros, de vertentes teórico-discursivas diferentes. Essa interlocução se realiza, entretanto, sem grandes sucessos, dada a incompatibilidade dos direcionamentos ideológicos que constituem tais projetos. Assim, é possível encontrar: a) ênfases a determinados discursos, os quais, a nosso ver, regem mais proficuamente a base; e b) contradições discursivas que apontam para uma tentativa de conciliação ideológica, mas que acabam por deixar entrever sua maior intenção e sua concepção ideológica mais fortalecida.

Seguem os núcleos discursivos que nossa análise permitiu discriminar. Antes, porém, segue um trecho introdutório do capítulo 5, "A etapa do Ensino Médio", da BNCC, que serve de justificativa para os propósitos da base e para o modo como ela foi organizada, preparando o terreno para a proposição de valores que a estruturam. Pautando-se pelo Parecer CNE/CEB n. 5/2011, que expõe a necessidade de recriação de uma escola que amplie as condições de inclusão social, com acesso à ciência, à tecnologia, à cultura e ao trabalho, o documento da base esclarece que:

\footnotetext{
RECORTE $1^{6}$

Para responder a essa necessidade de recriação da escola, mostra-se imprescindível reconhecer que as rápidas transformações na dinâmica social contemporânea nacional e internacional, em grande parte decorrentes do desenvolvimento tecnológico, atingem diretamente as populações jovens e, portanto, suas demandas de formação. Nesse cenário cada vez mais complexo, dinâmico e fluido, as incertezas relativas às mudanças no mundo do trabalho e nas relações sociais como um todo representam um grande desafio para a formulação de políticas e propostas de organização curriculares para a Educação Básica, em geral, e para o Ensino Médio, em particular. (BNCC, 2017, p. 462, Grifos nossos).
} 
Por esse excerto 1, é possível vislumbrar a descrição do contexto contemporâneo ou pósmoderno, conforme autores frequentemente nomeiam e caracterizam o período atual. Segundo Bauman (2001), um dos pesquisadores mais conhecidos sobre Pós-modernidade, a contemporaneidade é um momento de liquidez e de influências tecnológicas; sem paradigmas de valores fixos ou certezas imutáveis que conduzam a vida e a formação dos sujeitos; um período de interação intensa ocasionada pela globalização e pelo capitalismo, mas também de grandes instabilidades sociais, econômicas, identitárias, que são, muitas vezes, nomeadas de crises. É a partir desse contexto que a BNCC busca justificativas para os direcionamentos que estabelece para a educação brasileira, sem problematizar, todavia, os aspectos negativos do capitalismo e da racionalidade neoliberal. $\mathrm{O}$ que cobramos do documento não é a supressão da concepção pós-moderna da sociedade ou a indiferença aos regimes de verdade que regem a vida pós-moderna. Salientamos, sim, a necessidade de explicitar as contradições que esses regimes nos impõem. Se por um lado as tecnologias digitais e a globalização permitiram, por exemplo, romper fronteiras de comunicação; por outro, as culturas de massas se fortaleceram, fragilizando manifestações culturais de menores projeções. A ideia de diversidade pode advir como imperativo social contemporâneo, mas as influências de culturas de prestígio, como a norte-americana, ganharam mais alcance e temos visto discriminações cada vez mais frequentes contra grupos minoritários, em práticas de racismo e de xenofobia. Esse tipo de reflexão converge com uma concepção de educação que reconhece as historicidades, os sentidos cristalizados, as evidências naturalizadas e busca, sobretudo, encará-las, escancará-las, tornando a sala de aula um palco de reflexões e de espírito crítico, e não um meio de reprodução discursiva ou de pensamento que se aloja no conforto da adaptação ao momento sócio-histórico. Uma pedagogia libertadora, como propõe Freire (2005), é aquela que causa revolução no pensamento e que, por não apagar as contradições do capitalismo e da sociedade de classes, leva o sujeito a pensar em seu contexto, em sua história, em suas relações sociais e culturais que o constituem, para, a partir disso, caminhar para a transformação social, a qual se inicia, pois, no espírito crítico, analítico e engajado politicamente. Essa noção de formação humana e transformadora não se instaura como cerne da base curricular, conforme apontou a análise que aqui apresentamos.

Seguem três subitens e suas respectivas predominâncias discursivas.

\subsection{Protagonismo e Projeto de Vida}

Na seção "As juventudes e o Ensino Médio", que se inicia na p. 462 da BNCC, são indicadas as necessidades sociais e como deve ser o perfil do jovem para a sociedade contemporânea. As noções de participação ativa, protagonismo, autonomia e projeto de vida são, constantemente, ressaltadas, como fundamentais na formação que se pretende oferecer, regida pela base (BNCC, 2017, p. 463. Grifos do documento).

RECORTE 2: 
Considerar que há muitas juventudes implica organizar uma escola que acolha as diversidades, promovendo, de modo intencional e permanente, o respeito à pessoa humana e aos seus direitos. E mais, que garanta aos estudantes ser protagonistas de seu próprio processo de escolarização, reconhecendo-os como interlocutores legítimos sobre currículo, ensino e aprendizagem. Significa, nesse sentido, assegurar-lhes uma formação que, em sintonia com seus percursos e histórias, permita-lhes definir seu projeto de vida, tanto no que diz respeito ao estudo e ao trabalho como também no que concerne às escolhas de estilos de vida saudáveis, sustentáveis e éticos.

Comentamos, primeiramente, a restritiva empregada na construção sintática "uma escola que acolhe as diversidades", a qual deixa entrever uma intenção de designar a criação de um determinado tipo de escola - aquela que acolhe as diversidades - e de subentender que há escolas que são diferentes, isto é, que não acolhem as diversidades. Essa forma sintática é empregada nos momentos seguintes à página 463, com a formulação "a escola que acolhe a juventude", referida a toda escola que aceite os pressupostos e diretrizes da base, a qual propõe o acolhimento das diversidades e das juventudes, que são diversas. A maneira de nomear a escola que reconhece os valores da base desvela o seu contrário: o fato de haver escolas (educadores, pesquisadores, entidades etc.) que não os reconhecem ou não os aceitam. No entanto, mais que isso, considerando todo o contexto conflituoso que envolveu a elaboração e a aprovação da BNCC, com inúmeras críticas feitas a ela, entendemos que há um jogo discursivo por meio do qual aqueles que tecem críticas ao documento não são considerados simplesmente críticos ou opositores aos fundamentos que nele se inserem, mas são, sim, vistos como "contra" a diversidade e contra as juventudes. É uma forma de nomear a realidade e, ao mesmo tempo, de produzi-la, designando opositores de um discurso como opositores da sociedade (ou, neste caso, da juventude). Esse funcionamento discursivo pode ser observado, por exemplo, no enunciado "Brasil: ame-o ou deixe-o" (slogan disseminado no período da ditadura militar), segundo o qual aqueles que criticavam o sistema eram considerados contra o próprio país, uma vez que os discursos alinhados ao poder ditatorial se autovinculavam - por eles mesmos - como "os sentidos que querem o bem do país". Logo, os sentidos contrários eram vinculados à ideia de "aqueles que são contra o país". Entendemos que há esse mesmo funcionamento discursivo materializado recorrentemente no texto da base e sempre em destaque, em negrito: "[...] Para tanto, a escola que acolhe as juventudes precisa se estruturar de maneira a [...]" (BNCC, 2017, p. 466. Destaque do documento).

Ainda sobre o recorte 2, observamos, de forma explícita, a priorização do protagonismo e da definição do projeto de vida, conforme o próprio documento destaca. O primeiro está atrelado à participação ativa na sociedade; o segundo, ao vislumbramento do futuro responsável e planejado. São duas noções importantes. Nossa reflexão, porém, gira em torno da análise dos vínculos discursivos e ideológicos aos quais essa ideia de autonomia está conectada. Observando o contexto de produção da BNCC, relacionando esse contexto às justificativas introdutórias do documento e analisando os discursos que ressoam ao longo de 
todo o texto, concluímos que essa perspectiva de autonomia não é aquela que, ao considerar a realidade sócio-histórica e os fatores que a produziram, assume uma posição crítica, questionadora e, principalmente, transformadora. A ideia recorrente na base é a de sujeito livre, individualizado, dono de seu futuro, o qual pode ser realizado a partir de escolhas. Retomamos um trecho específico do excerto 2: "[...] permita-lhes definir seu projeto de vida, tanto no que diz respeito ao estudo e ao trabalho como também no que concerne às escolhas de estilos de vida saudáveis, sustentáveis e éticos [...]".

Uma vez dono de si e de seu futuro, o sujeito precisa se preparar, conforme encaminha a base (2017, p. 463. Destaques nossos):

\section{RECORTE 3:}

Para formar esses jovens como sujeitos críticos, criativos, autônomos e responsáveis, cabe às escolas de Ensino Médio proporcionar experiências e processos que lhes garantam as aprendizagens necessárias para a leitura da realidade, o enfrentamento dos novos desafios da contemporaneidade (sociais, econômicos e ambientais) e a tomada de decisões éticas e fundamentadas.

Os efeitos de sentidos evocados pelos adjetivos "críticos", "criativos", "autônomos" e "responsáveis" precisam ser analisados juntamente com reflexões que busquem as formações discursivas e ideológicas em que esses sentidos se inscrevem. Com a análise da base, é possível localizá-los no cerne da visão neoliberal, que demanda mão de obra não mecanizada (estereotípica de fábricas), mas, sim, sujeitos ativos, inventivos, autônomos, participativos; críticos para tomar decisões; responsáveis por suas escolhas. Seriam sujeitos que estariam constantemente em busca de ampliação de seu capital humano, pois assumem o papel de único responsável por seu projeto de vida e, consequentemente, também terão o mérito ou o demérito por isso. Abre-se a interlocução com a ideia de meritocracia, de indivíduo que, apesar de suas condições sócio-históricas, escreve seu futuro à sua escolha e por merecimento. Emerge a noção de que aquele que investe mais em seu capital humano pressupostamente terá um projeto de vida melhor e poderá colher os frutos disso. Essa lógica se ancora na possibilidade de livre escolha e, como vimos na concepção de neoliberalismo, na incitação à concorrência.

Retomamos aqui Marshall (2011), que alega que, para Foucault, a liberdade e o direito de as pessoas fazerem suas próprias escolhas, com base no fato de que são autônomas, é um embuste "que obscurece as formas pelas quais a compreensão que temos de nós mesmos como pessoas capazes de efetuar escolhas livres e autônomas é, ela própria, uma construção que nos permite ser governados, tanto individual quanto coletivamente" (MARSHALL, 2011, p. 22), afinal, o governo está relacionado à conduta da conduta. Trata-se de uma forma de atividade que visa a produzir sujeitos,

[...] a moldar, a guiar ou a afetar a conduta das pessoas de maneira que eles se tornem pessoas de um certo tipo; a formar as próprias identidades das pessoas de maneira que elas possam ou devam ser sujeitos. Essa atividade diz respeito às relações privadas entre o eu e o eu, ou as relações privadas interpessoais com 
mentores profissionais, ou a relações com instituições e comunidade, com o exercício da soberania política. A arte do governo consistiria em fornecer uma forma de governo para cada um e para todos, mas de forma que deve individualizar e normalizar (MARSHALL, 2011, p. 29).

Os "novos desafios da contemporaneidade", citados e destacados no recorte 3 , devem ser enfrentados. Dito de outra forma, é necessário, segundo o discurso da base, um sujeito proativo que, em vez de cobrar responsabilidades das instâncias de poder, enfrenta ele mesmo as questões, ou seja, há a desoneração do Estado e sua naturalização. A ênfase aos novos desafios silencia os velhos - e ainda não resolvidos - desafios históricos. Ocorre, pois, um apagamento das contradições e da historicidade das problemáticas sociais, o que pode levar à sua naturalização e, por consequência, sua reprodução.

\subsection{Sociedade da Aprendizagem e Sujeito adaptável}

É visível na BNCC o discurso neoliberal que instaura a ideia de sociedade aprendente ou sociedade da aprendizagem. O documento apresenta que, para alcançar as finalidades que pontua para o ensino, "[...] é necessário, em primeiro lugar, assumir a firme convicção de que todos os estudantes podem aprender e alcançar seus objetivos, independentemente de suas características pessoais, seus percursos e suas histórias [...]” (BNCC, 2017, p. 465. Destaque nosso). Nesse trecho, chama atenção a ênfase, novamente, que se dá para a ideia de escolha. Embora haja, também, o efeito de sentido alinhado à inclusão e à democratização do ensino, ocorre o apagamento das contradições e das questões de classe, que são sóciohistóricas. Salientamos que a insistência em comentar esse movimento concretizado no texto da base seria uma resposta necessária por não corroborar o que o documento faz, a saber: naturalizar as problemáticas, os vestígios históricos de sentido e de lutas sociais; naturalização essa que pode contribuir para a manutenção dessas questões. É claro que todos os estudantes são capazes de aprender. A descrença nisso não faz parte de objetivos de uma escola realmente democrática e dos direitos de todos os cidadãos. No entanto, isso não está desvinculado das características pessoais nem tampouco dos percursos e das histórias dos alunos. Negar esses vínculos é silenciar as desigualdades do país e ratificar o equívoco de que todos podem chegar aos mesmos resultados, bastando apenas ter vontade e esforçar-se.

Voltando aos imperativos como "aprender a aprender" (recorrentemente citados: p. 489, 490 etc.) e "continuar aprendendo" (p. 464, 466, 467, 490, 491 etc.), observamos que eles fazem parte da mesma formação discursiva em que o neoliberalismo e o capital humano indicam as diretrizes de funcionamento social em uma sociedade contemporânea que se faz pela dinamicidade e flexibilidade. Diferentemente da ideia de incompletude humana, o discurso que funda a lógica da sociedade da aprendizagem coloca o conhecimento como mercadoria que deve ser consumida e acumulada, pois, como objeto de consumo, está à mercê da obsolescência. Assim, a ideia de contínuo da aprendizagem entrevista no documento está menos em favor de um sujeito que se vê incompleto e que se tece na relação 
de alteridade, e está mais em favor de um sujeito que é impulsionado a investir em si mesmo, que se vê como responsável por seu futuro (econômico), que é ele mesmo a empresa de si. Para se adaptar à realidade descrita em termos de cidadania e de trabalho, são necessárias habilidades e competências que formem esse sujeito flexível, como se observa no recorte 4.

\section{RECORTE 4:}

Essas experiências, como apontado, favorecem a preparação básica para o trabalho e a cidadania, o que não significa a profissionalização precoce ou precária dos jovens ou o atendimento das necessidades imediatas do mercado de trabalho. Ao contrário, supõe o desenvolvimento de competências que possibilitem aos estudantes inserir-se de forma ativa, crítica, criativa e responsável em um mundo do trabalho cada vez mais complexo e imprevisível, criando possibilidades para viabilizar seu projeto de vida e continuar aprendendo, de modo a ser capazes de se adaptar com flexibilidade a novas condições de ocupação ou aperfeiçoamento posteriores. Para tanto, a escola que acolhe as juventudes precisa se estruturar de maneira a [...]. (BNCC, 2017, p. 464 e 465. Destaques do documento).

Primeiramente, ficam subentendidas, no recorte 4, vozes contrárias que ressoam ao que coloca o documento. A afirmação nesse excerto de que a formação proposta "não significa a profissionalização precoce ou precária dos jovens ou o atendimento das necessidades imediatas do mercado de trabalho" apenas deixa escapar que há forte tendência a se interpretar o contrário. É para se contrapor a uma voz que denuncia o caráter empresarial, mercadológico e precarizado da formação que se vislumbra oferecer aos estudantes, que o texto do documento vê a necessidade de reafirmar seu posicionamento, como uma réplica. Os signos refletem e refratam sentidos (BAKTHIN, 2006). Desse modo, vemos refratar o discurso oposto que, por emergir com força (e por incomodar), foi contraposto textual e enunciativamente.

Ainda pelo recorte 4, é possível observar a relação que a base estabelece entre o perfil do egresso (sujeito ativo, crítico, criativo, responsável), o enfoque do Ensino Médio (preparar, em primeiro plano, para o trabalho; em segundo, para a cidadania), os modos para a formação (ensino por habilidades e competências, não necessariamente por conteúdos e conhecimentos construídos) e, principalmente, a finalidade dessa educação (proporcionar a formação de um sujeito que seja adaptável e flexível ao imprevisível da contemporaneidade capitalista).

A ideia de adaptabilidade e flexibilidade acompanha os discursos da sociedade da aprendizagem e do incessante investimento em capital humano. Acompanha, também, a lógica de individualização do sujeito, que, quanto mais flexível, melhor se adaptará às crises e às adversidades, sobretudo, financeiras. Um sujeito competente é supostamente eficiente para o sistema e um tipo de mão de obra que consegue se moldar aos diversos tipos de trabalho ou mesmo de empreender autonomamente. Nessa perspectiva, silenciam-se os discursos de coletividade, de saídas coletivas para problemas sociais, de transformação da realidade. A transformação social cede terreno para o discurso de adaptação social. O 
enfrentamento das contradições estruturais cede lugar para o discurso de flexibilidade diante dessas contradições e, por conseguinte, para a naturalização das condições históricas. $\mathrm{O}$ jogo de silenciamentos (ORLANDI, 2007) não impede que os discursos apagados continuem a ecoar, nas entrelinhas, nos diálogos, nos deslizamentos de efeitos de sentido.

Nesse direcionamento discursivo, o documento apresenta cinco pilares sob os quais a escola vista como acolhedora das juventudes - ou, como discursivamente interpretado, vista como aquela que está de acordo com os princípios e as diretrizes da base - deve se estruturar. Destacaremos os dois últimos, que têm ligação com a sociedade da aprendizagem e o sujeito adaptável, típicos da racionalidade neoliberal:

\begin{abstract}
RECORTE 5:
- proporcionar uma cultura favorável ao desenvolvimento de atitudes, capacidades e valores que promovam o empreendedorismo (criatividade, inovação, organização, planejamento, responsabilidade, liderança, colaboração, visão de futuro, assunção de riscos, resiliência e curiosidade científica, entre outros), entendido como competência essencial ao desenvolvimento pessoal, à cidadania ativa, à inclusão social e à empregabilidade; $\mathrm{e}$

- prever o suporte aos jovens para que reconheçam suas potencialidades e vocações, identifiquem perspectivas e possibilidades, construam aspirações e metas de formação e inserção profissional presentes e/ou futuras, e desenvolvam uma postura empreendedora, ética e responsável para transitar no mundo do trabalho e na sociedade em geral. (BNCC, 2017, p. 466. Destaques nossos).
\end{abstract}

Nesses dois últimos elementos estruturantes da escola que se vislumbra pela base, é explicitamente mencionada a cultura do empreendedorismo, ideia já despontada em outros trechos do texto, como competência essencial do sujeito. Da maneira como a atividade empreendedora foi caracterizada, no primeiro tópico, com a enumeração de elementos entre parênteses (destacados por nós), ficam evidentes os alinhamentos do documento com a lógica neoliberal de mercado e fica claro o perfil almejado de sujeito: empresário de si, criativo e resiliente para se adaptar às demandas e aos riscos do mundo capitalista.

Também podem ser identificados os discursos das práticas de coaching, segundo as quais se treinam os sujeitos para identificar oportunidades e traçar metas em busca de seus objetivos pessoais e profissionais, colocando tais ações como exclusivamente capazes de promover o sucesso na profissão ou no negócio que se buscou empreender. $\mathrm{O}$ alinhamento a essas práticas é entrevisto na indicação, no segundo tópico, de que a escola precisa propiciar que os alunos: "reconheçam suas potencialidades e vocações, identifiquem perspectivas e possibilidades, construam aspirações e metas de formação [...] desenvolvam uma postura empreendedora". São aconselhamentos característicos das esferas de gestão e administração empresariais. Dito de outro modo, quando se afirma, no último tópico, a necessidade de oferta de suporte aos jovens para que reconheçam potencialidades, identifiquem perspectivas, construam aspirações e metas, preparem-se para empreender..., $\mathrm{o}$ que se lê são discursos do mercado que chegam ao contexto da educação e buscam promover um ambiente de coaching ${ }^{7}$ (fenômeno de "coachingzação"), em que os professores seriam 
os coaches, o que nos remete ao "surto de aconselhamento" que tomou conta da sociedade, como apontado por Bauman (1998). O processo de ensino-aprendizagem fica nivelado ao desenvolvimento de competências, ao treino, ao atendimento de necessidades profissionais e do âmbito do mercado (consumo, investimento, empreendimento, aspiração de lucro, inovação). Ficam reduzidos os aspectos de uma educação sólida, baseada em conteúdos social e cientificamente construídos, fundamentais para o conhecimento e a criticidade. Esses enfoques estão implícitos no documento, mas seus vestígios emergem pela priorização de discursos neoliberais ou alinhados a eles (bem como pelo silenciamento de outros discursos), pela relação interdiscursiva, pela rede dialógica estabelecida marcada textual e enunciativamente no documento da BNCC.

A construção da rede discursiva que permeia e engendra a base também é marcada pela contradição. Isso porque o contexto em que o documento foi aprovado é também marcado por divergências ideológicas e por vozes que lutaram por espaço para estabelecer projetos diferentes de educação. Na tentativa de redes de diálogos e de acomodação discursiva, encontram-se parâmetros para as escolas como (BNCC, 2017, p. 467):

RECORTE 6:

- compreender que a sociedade é formada por pessoas que pertencem a grupos étnico-raciais distintos, que possuem cultura e história próprias, igualmente valiosas, e que em conjunto constroem, na nação brasileira, sua história;

- promover o diálogo, o entendimento e a solução não violenta de conflitos, possibilitando a manifestação de opiniões e pontos de vista diferentes, divergentes ou opostos;

E, na mesma sequência, parâmetros como:

RECORTE 7:

- combater estereótipos, discriminações de qualquer natureza e violações de direitos de pessoas ou grupos sociais, favorecendo o convívio com a diferença;

- valorizar sua participação política e social e a dos outros, respeitando as liberdades civis garantidas no estado democrático de direito; e

- construir projetos pessoais e coletivos baseados na liberdade, na justiça social, na solidariedade, na cooperação e na sustentabilidade.

Os parâmetros apresentados no recorte 6 produzem efeitos de sentido que se recolhem em uma formação discursiva e ideológica diferente dos efeitos de sentido produzidos pelos parâmetros apresentados no recorte 7 .

No recorte 6, as formas verbais "compreender" e "promover" ganham tom apaziguador, corroborando com a ideia de aceitação das diferenças, as quais são tomadas como naturais, próprias da sociedade, conforme as construções frasais afirmativas e enumerativas: "as pessoas pertencem a grupos étnico-raciais distintos", "possuem cultura e história próprias". A afirmação de que todas as culturas e grupos são igualmente valiosos e compõem a nação brasileira busca contrapor não só à voz que afirma que não são valiosos, mas, também, à voz que insiste em dizer que a igualdade ainda não é uma realidade e que, portanto, precisamos 
combater discursos que impedem sua concretização. Nesse tom valorativo, há, ainda, a ideia de "promoção do diálogo" e "o entendimento e a solução não violenta de conflitos", que não são proposições negativas; ao contrário, são necessárias. O que se reflete aqui, porém, é o apaziguamento, a indiferença aos choques ideológicos e à existência, ainda muito forte, de discursos discriminatórios, preconceituosos, racistas. O recorte 6 materializa, portanto, discursos que se vinculam à produção de corpos dóceis, não resistentes, apenas disciplinados e abertos a aceitar, não necessariamente a questionar. Não se espera, no discurso desse recorte, o efetivo combate a pontos de vista e a condutas que venham a ferir os direitos humanos, por exemplo. Novamente, há a naturalização do diferente, que deve ser, apenas, "aceito". Nessa esteira, a aceitação não precisa vir acompanhada de inclusão, empatia, convívio solidário.

Já o recorte 7 parece ir na direção contrária, denunciando a disputa de vozes no documento. A ideia de "combate a estereótipos", o destaque à importância de se pautar pelos "direitos humanos", a indicação por "valorizar participação política e social", a citação do "estado democrático de direito", a ênfase para projetos não só pessoais (como o projeto de vida) mas também "coletivos", com "justiça social”, são indicações enunciativas que vislumbram um outro direcionamento discursivo que destoa dos parâmetros apresentados no recorte 6. Aqui, tem-se a intencionalidade de marcar a educação com a função problematizadora da realidade, engajada política e socialmente, por meio da qual se combatem opiniões que violem os direitos humanos, não apenas as aceitem, com a justificativa de serem diferentes. A ideia de coletividade, escassa ao longo do documento, também fica evidente no recorte 7, ultrapassando o discurso que individualiza o sujeito.

\subsection{Disciplina e Controle}

Conforme expõe Veiga-Neto (2008), devido ao imperativo de mudança de ênfase da disciplina para o controle, os currículos tendem a seguir esse movimento, pensando novos procedimentos de controle. A BNCC é anunciada como uma proposta inovadora para o engendramento de currículos, com preocupação maior na ação (formação de professores, prática em sala de aula) e na avaliação (sobretudo as institucionais externas - o PISA etc. que validarão o mérito do alunado e do professorado). Quanto ao planejamento, ele já está apresentado pelo documento como modelo (quase que totalmente engessado, daí muitas críticas que a base sofre, pela não abertura às demandas de diversidade e pluralidade do país); e quanto à seleção de conteúdos, esta ficou em segundo plano, com o destaque para a proposta de trabalho por habilidades e competências.

A BNCC assume, por conseguinte, um caráter paradoxal: por um lado, surge com o rótulo de proposta curricular inovadora e traz valores e discursos pós-modernos, desvendando a crise disciplinar (do corpo e do saber) por que passamos, como um efeito da crise da Modernidade; mas, por outro lado, ela é tão fechada e arraigada a campos de saberes (no fundo, rearranjos de disciplinas) e à delimitação de habilidades e competências, que acaba por (re)produzir o desejo de máquina disciplinar moderna. Vê-se, pois, uma flutuação 
discursiva entre a disciplinarização e o dispositivo de controle. Ainda no primeiro caso, a base emerge como "resposta" à crise educacional brasileira, assumindo diálogo com práticas do neoconservadorismo por se autodefinir como uma resposta a um suposto "caos". Vejamos como a (des)disciplinarização é apresentada no texto da base:

\section{RECORTE 8:}

Para atender a todas essas demandas de formação no Ensino Médio, mostra-se imperativo repensar a organização curricular vigente para essa etapa da Educação Básica, que representa excesso de componentes curriculares e abordagens pedagógicas distantes das culturas juvenis, do mundo do trabalho e das dinâmicas e questões sociais contemporâneas.

$\mathrm{Na}$ direção de substituir o modelo único de currículo do Ensino Médio por um modelo diversificado e flexível, a Lei n. 13.415/2017 alterou a LDB, estabelecendo que "O currículo do ensino médio será composto pela Base Nacional Comum Curricular e por itinerários formativos, que deverão ser organizados por meio de oferta de diferentes arranjos curriculares, conforme a relevância para o contexto local e a possibilidade dos sistemas do ensino [...]". (BNCC, 2017, p. 467 e 468. Destaques nossos).

Sobre os itinerários formativos, é importante salientar que há inúmeras discussões sobre sua viabilidade e suas consequências para os jovens, sobretudo de classes desprivilegiadas. A escolha precoce por um itinerário pode ser desastrosa e determinada não por desejo ou aptidão pessoais, como o documento preconiza, mas por ser a única opção ofertada pela escola e/ou localidade do aluno. Ademais, o itinerário técnico profissionalizante, conforme outros momentos históricos e exemplos de outros países já mostraram, acaba por ser a "escolha" da classe trabalhadora, que vê nesse itinerário uma forma de ampliar suas condições de empregabilidade, o que não necessariamente caminha junto com a sua entrada nas universidades. Apesar de produtiva discussão, não será desenvolvida neste artigo, para o qual delimitamos outros objetivos.

Como se constata, na leitura do excerto acima, recorte 8 , há uma tentativa de desvio da organização disciplinar do currículo, vista pela BNCC como excesso de componentes curriculares e de abordagens pedagógicas distantes das juventudes. A base propõe, portanto, não o trabalho exatamente com disciplinas, embora a dissolução delas não seja indicada, mas, sim, com áreas do conhecimento e, no caso do Ensino Médio, com itinerários formativos, que se mostram como uma tentativa pós-moderna de negar a organização disciplinar e de manter o dispositivo de controle.

Nesse entremeio da disciplina e do controle, observamos a subjetivação do sujeito disciplinado e flexível. Veiga-Neto (2008, p. 147) assim o caracteriza:

[...] um sujeito dócil é um sujeito fácil de manejar/conduzir porque aprendeu, assumiu e "automatizou" certas disposições mentais-corporais mais ou menos permanentes. O dócil, tendo sido objeto das estratégias disciplinares, fazem delas parte de sua alma, de modo que submete-se a elas, por si mesmo; eles são capazes 
de se autogovernarem. Um sujeito flexível é diferente: ele é permanentemente tático. Por isso, na busca de maior eficácia para atingir seus objetivos, o sujeito flexível apresenta comportamentos adaptativos e está sempre preparado para mudar de rumo, de modo a enfrentar melhor as mudanças. A docilidade, por ser estável e de longa duração, é da ordem da solidez moderna; a flexibilidade, por ser adaptativa, manhosa, é da ordem da liquidez pós-moderna.

Percebe-se, com aproximação às reflexões de Veiga-Neto (2008), o quanto um sujeito flexível pode ser mais produtivo à ordem social neoliberal, daí a pretensão de atuar nas reformulações curriculares e demais instrumentos escolares que podem operar na formação e, principalmente, no controle dos sujeitos.

Sobre o que expõe acerca das características dos sujeitos disciplinados e flexíveis, pontuamos que, a nosso ver, o sujeito flexível é menos politizado, mais adaptável, mais conformado. É como se não valesse a pena engajar-se numa questão política/social que enfrente e transforme as problemáticas sociais, pois, assim como as estratégias de mercado, tudo logo irá mudar (não necessariamente melhorar para alguns grupos), e o sujeito terá de se adaptar novamente. Esse traço de funcionamento discursivo é produtivo para o sistema imanentista, neoliberal, em que o controle vale mais que a disciplina, porque a disciplina é rígida e o mercado precisará de novos sujeitos. No entanto, consideramos que esse sujeito flexível tem menos força de fazer frente à crise, é menos livre (posto que mais controlado, sob a sensação de liberdade), menos atuante, mais individualizado/individualista; e a luta por transformação social coletiva perde força.

\section{Algumas considerações "finais"}

Cientes do caráter inconcluso de todo enunciado, cujo fechamento está no outro, sendo, pois, apenas parte de uma rede discursiva (BAKHTIN, 2006), encaminhamos algumas palavras "finais". Não temos, por conseguinte, intuito de fechar a reflexão ou de tomar as análises como definitivas ou completas, uma vez que poderão fazer ecos discursivos e suscitar réplicas enunciativas a partir das leituras que possam ser estabelecidas do e pelo artigo.

Desse modo, pelas discussões desenvolvidas, entendemos que a BNCC é constituída no entremeio: entre a sociedade disciplinar moderna e a de controle pós-moderna; e se destaca pela aposta na governamentalidade neoliberal, na conduta da conduta, como aponta estudos de Foucault, em diversas de suas obras. Assim, como discutimos, o planejamento de objetivos e a seleção de conteúdos perdem relevância, a qual é direcionada aos modos como os conteúdos serão colocados em ação na prática pedagógica e aos modos de avaliação - modos estes que servirão para tutelar o trabalho docente. Emergem demandas por relatórios, avaliações escritas, registros de aulas, planejamentos, planos de ensino. Vivem-se mudanças constantes nos formatos de materiais, acompanhando novas metodologias, inovações teóricas. São elementos feitos para serem consumidos com a suposta justificativa de 
aprimoramento, mas que, na verdade, procuram fiscalizar e controlar. Deixam, ainda, escapar a condição incontrolável do próprio sujeito, sobretudo, do sujeito da pós-modernidade, e é nessa e por essa condição que a experiência de si pode se corporificar.

Finalmente, definimos e caracterizamos a BNCC, que se apresenta como parte da maquinaria discursiva neoliberal: o documento opera como dispositivo de controle das práticas do próprio professor e da formação dos alunos na qual o docente tem função essencial. A base atua em novos processos de subjetivação e, assim, no engendramento de novas subjetividades. Não é por acaso que inúmeras organizações de caráter privado tomaram parte nas discussões e na sugestão de competências e habilidades que deveriam compor o documento final, de acordo com o que vimos na seção em que tratamos da contextualização da BNCC.

Nesse sentido, cabem os questionamentos: a quem servem os discursos que constituem a BNCC? Para onde vai a educação brasileira ou quais direcionamentos se esperam para ela? Refletir sobre essas questões pode auxiliar em respostas que venham a se materializar para os dispositivos de controle a que estamos submetidos. E ainda, aproximando-nos do que observa Favacho (2016) sobre as pesquisas acerca do currículo, consideramos que as atitudes críticas e éticas diante dos discursos "oficiais" que nos chegam podem contribuir para a abertura de caminhos que pesquisas e práticas no âmbito da educação podem percorrer, implicando sujeitos e experiências de si, além de potencializar as brechas pelas quais os sujeitos podem operar nos acontecimentos discursivos.

\section{Notas:}

1. Citação de Favacho (2016): FOUCAULT, M. O que são as luzes. In: Ditos e Escritos II. Foucault: Arqueologia das Ciências e História dos sistemas de pensamento. Organizado por Manuel Barros da Motta. Tradução Elisa Monteiro. Rio de Janeiro: Forense Universitária, 2000..

2. Faz-se prudente uma observação inicial: sob a perspectiva liberal, a constituição do capital humano, do ponto de vista da teoria que o institui, referia-se, em momento anterior, como o faz também no atual, ao investimento do Estado, da iniciativa privada ou do próprio sujeito na educação escolar, visando à inserção nas atividades do trabalho e sua produtividade no desempenho dele.

3. Referenciado por Batista (2019): DELEUZE, Gilles. Conversações (1972-1990). São Paulo: Editora 34, 1992.

4. Ambas as referências feitas por Veiga-Neto (2008): VARELA, J.; AVAREZ URÍA, F. Arqueoloาgía de la

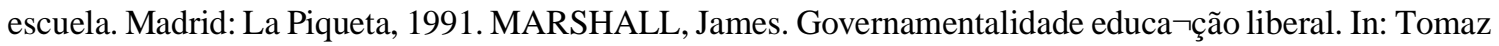
Silva (Org.). O sujeito da educaาção. Petrópolis: Vozes, 1994. pp. 2134.

5. Referenciação de Veiga-Neto (2008): POPKEWITZ, Thomas. História do currículo, regu $\neg$ lação social e poder. In: Tomaz Silva (Org.). O sujeito da educação. Petrópolis: Vozes, 1994. pp. 173210.

6. Os recortes ou excertos feitos da BNCC para análise serão numerados, a fim de melhor alcançar coesão e coerência textuais.

7. O termo coaching apareceu pela primeira vez na era medieval, com a figura do cocheiro, o homem que conduzia a carruagem (coche) para algum lado. Os cocheiros também eram especialistas em treinar os cavalos, para que estes puxassem os coches. [... Atualmente,] um coach pode ser uma pessoa que treina um 
atleta ou conjunto de atletas: a soccer coach - um treinador de futebol. Pode também ser uma espécie de tutor privado que prepara um aluno para um determinado exame ou uma pessoa que instrui um ator ou cantor. Quando relacionado com o coaching, o coach é um profissional qualificado e que utiliza metodologias, técnicas e ferramentas do coaching para o benefício de uma empresa ou de um indivíduo, quer na sua área pessoal ou profissional. O coach trabalha com um coachee (aprendiz ou aluno) com o objetivo de desbloquear nele dons e habilidade já existentes. Existem vários tipos de coaching, como o coaching pessoal, profissional, empresarial e financeiro, e por isso existem diferentes coaches que se especializam em áreas diferentes. Fonte: www.significados.com.br.

\section{Referências}

BAKHTIN, M. Marxismo e Filosofia da linguagem. 12. ed. São Paulo: HUCITEC, 2006.

BATISTA, B. N. Foucault e a genealogia do neoliberalismo. In: Movimento-Revista de Educação, Niterói, ano 6, n.11, p. 137-159, jul/dez. 2019.

BAUMAN, Z. O mal-estar da Pós-modernidade. Trad. GAMA, M.; GAMA, C. M. Rio de Janeiro: Zahar, 1998.

Modernidade líquida. Trad. Plínio Dentzien. Rio de Janeiro: Jorge Zahar, 2001.

BRASIL. Base Nacional Comum Curricular (BNCC). Brasília: MEC. 2018. Disponível em: <http://basenacionalcomum.mec.gov.br/images/BNCC_EI_EF_110518_versaofinal_site.pdf> Acesso em: 01 ago. 2020.

COSTA, S. de S. G. Governamentalidade neoliberal, Teoria do Capital Humano e Empreendedorismo. In: Revista Educação \& Realidade. 34(2):171-186, mai/ago., 2009.

FAVACHO, A. M. P. Currículo, subjetivação e experiência de si: contra os humanismos, os modismos e os relatos obtusos. In: Currículo sem Fronteiras, v. 16, n. 3, p. 488-508, set./dez., 2016.

FERNANDES, C. A. Análise do discurso: reflexões introdutórias. 2. ed. São Carlos: Claraluz, 2007.

FIMYAR, O. Governamentalidade como ferramenta conceitual na pesquisa de políticas educacionais. Educação \& Realidade, v. 34, n. 2, mai./ago. 2009.

FONTOURA, C. T. Michel Foucault e a problematização do poder. In: INTUITIO. v.1, n. 2, nov., pp. 68-88, Porto Alegre, 2008.

FOUCAULT, M. História da sexualidade I: a vontade de saber. 15. ed. Rio de Janeiro: Edições Graal, 1988. . Nascimento da biopolítica: curso dado no Collège de France (1978-1979). Tradução de Eduardo Brandao. São Paulo: Martins Fontes, 2008.

Vigiar e punir: nascimento da prisão. 37. ed. Petrópolis: Vozes, 1987.

FREIRE, Paulo. Pedagogia do oprimido. 45. ed. São Paulo: Paz e Terra, 2005.

MARSHALL, J. Governamentalidade e educação liberal. In: SILVA, T. S. (Org.) O sujeito da Educação: estudos foucaultianos. 8. ed. Petrópolis: Vozes, 2011.

ORLANDI, E. P. Análise de discurso: princípios e procedimentos. 6. ed. Campinas, SP: Pontes, 2005.

As formas de silêncio: no movimento dos sentidos. 6. ed. Campinas: Editora da Unicamp, 2007.

PÊCHEUX, M. Discurso e ideologia(s). In: ___. Semântica e discurso: uma crítica à afirmação do óbvio. Trad. Eni P. Orlandi et al. 5. ed. Campinas, SP: Ed. da Unicamp, 2014. p. 127-168.

O discurso: estrutura ou acontecimento. Trad. Eni P. Orlandi. 7. ed. Campinas, SP: Pontes, 2015.

PERONI, V. M. V.; CAETANO, M. R.; ARELARO, L. R. G. BNCC: disputa pela qualidade ou submissão da educação? In: RBPAE. v. 35, n. 1, p. 035 - 056, jan./abr., 2019.

SILVA, F. N.; BARREIRO, A. Apontamentos sobre educação e neoliberalismo a partir de Michel Foucault: propostas iniciais. In: Universitas. Ano 13, n. 25, jul/dez., 2019.

SIMONS, M.; MASSCHELEIN, J. Sociedade da aprendizagem e governamentalidade: uma introdução. In: 
Currículo sem Fronteiras, v.11, n.1, pp.121-136, Jan/Jun., 2011.

VEIGA-NETO, A. Crise da modernidade e inovações curriculares: da disciplina para o controle. In: Sísifo: revista de ciências da educação. n. 7, set/dez., 2008.

\section{Correspondência}

Viviane Dinês de Oliveira Ribeiro Bartho: é vinculada ao Instituto Federal de São Paulo, campus Campos do Jordão - IFSP/CJO.

E-mail: viviane_dines@yahoo.com.br

Luciana Aparecida Silva de Azeredo: é vinculada ao Centro Federal de Educação Tecnológica de Minas Gerais - CEFET-MG.

E-mail: luazeredo@gmail.com

Texto publicado em Currículo sem Fronteiras com autorização dos autores. 